\section{EGÉSZSÉGBIZTOSÍTÁS A PTK.-BAN - A MAGÁN-EGÉSZSÉGBIZTOSÍTÁS JELENE ÉS PERSPEKTÍVÁI}

\section{Dr. Tökey Balázs (ELTE ÁJK, adjunktus)}

\section{ÖSSZEFOGLALÓ}

Tanulmányunk elsősorban a Ptk. egészségbiztositási szerződésekre vonatkozó újonnan bevezetett szabályozásának legfontosabb elemeit mutatja be. Emellett röviden ismertetjük a magán-egészségbiztosítások hazai helyzetét és a várható kilátásokat. Megállapítható, hogy arra és az egészségbiztosítási szerződések gyakorlatára a Ptk. hatálybalépése nem lehetett jelentős hatással, ezért röviden kitérünk arra is, hogy milyen változásokra lenne szükség az egészségbiztosítások hazai elterjedéséhez.

\section{SUMMARY}

Our paper primarily interprets the most important elements of the new regulation on health insurance contract in the new Hungarian Civil Code. In addition, we briefly describe the situation of private health insurance market in Hungary and the expected perspectives. It is clear that the new regulation of the Hungarian Civil Code could not have a significant influence on the practice of health insurance so we also briefly mention those changes that would be needed to the spread of health insurances in Hungary.

Kulcsszavak: egészségbiztosítás, magánegészségügy, piaci helyzet, Ptk., szolgáltatásfinanszírozás

Keywords: health insurance, private healthcare, market situation, Civil Code, in kind model

JEL: K12

DOI: $10.18530 /$ BK.2018.1.62

http://dx.doi.org/1018530/BK.2018.1.62

\section{Bevezetés}

A Polgári Jogot Oktatók XXIII. Országos Találkozóján, 2017. november 10-én, Miskolcon, „A biztosítás aktuális kérdései a jogtudomány szemével elnevezésư” konferencián megtartott előadás, melynek címe megegyezik a jelen tanulmányéval, egyrészt azt kívánta bemutatni, hogy melyek a Polgári Törvénykönyvről szóló 2013. évi V. törvény (a továbbiakban: Ptk.) egészségbiztosítási szerződésekre vonatkozó újonnan bevezetett szabályozásának legfontosabb elemei. Emellett a kapott felkérésre tekintettel arra is kitért röviden, hogy hazánkban jelenleg hogy néz ki a magán-egészségbiztosítás helyzete, és milyenek a jövőbeli kilátások. Éppen ezért rövid tanulmányunkban a fentieken túl még azt a kérdést vizsgáljuk, hogy a Ptk. hatálybalépése hozott-e valamilyen változást az egészségbiztosítási szerződések gyakorlatában, mennyiben volt hatása az egészségbiztosítási piacra.

\section{Az egészségbiztosítási szerződések Ptk.-beli szabályozásának sarokpontjai}

A Magyar Köztársaság Polgári Törvénykönyvéről szóló 1959. évi IV. törvény (a továbbiakban: 1959-es Ptk.) az egészségbiztosítási szerződések vonatkozásában nem tartalmazott különös szabályokat. A polgári jognak az 1990-es évek végén indult rekodifikációja során azonban a felmerült társadalmi igények kielégítése céljából (lásd a Ptk. miniszteri indoklását) megfogalmazódott e szerződéstípus kódexbe való beemelésének a lehetősége. A szabályozás kidolgozása során három fontosabb kérdés merült fel:

- mi legyen ennek az új szerződéstípusnak a neve;

hogyan lehet beilleszteni az egészségbiztosítási jogviszonyt a többi biztosítási szerződés közé;

- hogyan lehet meghatározni az egészségbiztosítási szerződés fogalmát.

Az elnevezés kapcsán két lehetőség merült fel: a betegségbiztosítás és az egészségbiztosítás. Az elsőben a jellemző biztositási esemény jelenik meg a szerződéstípus nevében (ugyanúgy, mint pl. a balesetbiztosításnál), a másodikban pedig a biztosított kockázat (ugyanúgy, mint pl. az életbiztositás esetén). Az első elnevezés mellett többek között azzal lehetett érvelni, hogy így könnyebb elkülöníteni a magánbiztosításokat a társadalombiztosításnak a kötelező egészségbiztosítási ágától. Emellett a betegségbiztosítás kifejezést használták az egyéb jogszabályok is a magánbiztosítások leírására (lásd pl a korábbi Bit-et, azaz a biztosítókról és a biztosítási tevékenységről szóló 2003. évi LX. törvényt vagy az Ebktv.-t, azaz az egyenlő bánásmódról és az esélyegyenlőség előmozdításáról szóló 2003. évi CXXV. törvényt).

Ugyanakkor több érvet lehetett az egészségbiztosítási szerződés elnevezés mellett is felhozni. Például nem csak betegség lehet a biztosítási esemény (lásd pl. az egészséges vagy balesetet szenvedett biztosítottaknak nyúitott szolgáltatások alapját képező biztosítási eseményeket). Emellett az egészség szó használata mindenképpen pozitívabb tartalmat hordoz, mint a betegség. Éppen ezért egyetértünk azzal, hogy az elfogadott Ptk. - ellentétben a 2008-as Szakértői Javaslattal 
és a végül hatályba nem lépett, a Polgári Törvénykönyvről szóló 2009. évi CXX. törvénnyel (a továbbiakban: 2009-es Ptk.) - az egészségbiztosítás elnevezést használja.

A Ptk. a Principles of European Insurance Contract Law-t (PEICL) követve az egyes biztosításokat a szerint csoportosítja és szabályozza, hogy azok kár- vagy összegbiztosításnak minősülnek-e. Az előbbinél a biztosító szolgáltatása a biztosítottat ért vagyoni kár megtérítése, az utóbbinál pedig a biztosítónak a biztosítási esemény bekövetkeztekor az előre meghatározott összeget kell megfizetnie, függetlenül attól, hogy a biztosítási eseménynek milyen hatása van a biztosított vagyoni helyzetére. Ez az új felosztás azzal járt, hogy az egészségbiztositásokat nem lehetett e rendszerben egyértelműen elhelyezni, mert azok lehetnek összeg- (pl. kritikus betegségekre szóló biztosítások, melyek lényege az, hogy a biztosító akkor fizeti ki a biztosítási összeget, ha a biztosítottnál fellép a biztosítási szerződésben meghatározott betegség) és kárbiztosítások (pl. orvosi költségeket fedező biztosítások) is. Így a Ptk. kényszerűségből az egészségbiztosításokat a kárbiztosítások és az összegbiztosítások után külön, önálló fejezetben helyezte el. Ez a megoldás azonban több szempontból sem bizonyult szerencsésnek. Egyrészt nem elegáns, mert a jogalkotó létrehozott egy struktúrát, de abba az egészségbiztosítást nem tudta beilleszteni. Másrészt e „mostoha sors” és a szabályozás felépítésének kodifikáció alatti módosulása következtében az egészségbiztosítási szerződésnek a kár- és összeg-, illetve életbiztosításokra visszautaló szabályai gyakran hiányosak vagy ellentmondásosak, és több értelmezési kérdést vetnek fel: például nem egyértelmű, hogy a megjelölt kárbiztosítási rendelkezéseket az összegbiztosításnak minősülő egészségbiztosításokra is alkalmazni kell-e, valamint a Ptk. indokolatlanul nem utal vissza az életbiztosítási szabályok közül a várakozási időre és a kedvezményezett kijelölésére vonatkozó rendelkezésekre.

\section{A Ptk. kényszerüségből az egészségbiztosításokat külön,} önálló fejezetben helyezte el.

Végül röviden szólunk még a Ptk.-nak az egészségbiztosítási szerződésekre vonatkozó definíciójáról. A Ptk. 6:487. \$-a azt rögzíti, hogy „egészségbiztosítási szerződés alapián a biztosító a biztosított megbetegedése esetén a szerződésben meghatározott szolgáltatások teljesítésére vállal kötelezettséget. A biztosító szolgáltatása kiterjedhet a szerződésben meghatározott egészségügyi szolgáltatások egészséges személy általi igénybevételekor felmerülő költségek megtérítésére is.” E meghatározás azonban álláspontunk szerint nem teljes, az kiterjesztően értelmezendő.

Először is a megbetegedés fogalmát tágan kell értelmeznünk: a biztosított kockázat ugyanis nem csupán egy betegség kialakulásának a lehetősége lehet, hanem egyéb egészségromlással kapcsolatos kockázatot is fedezhet egy egészségbiztosítás (pl. egy balesettel kapcsolatos kórházi ellátás költségei). Emellett hangsúlyozzuk azt is, hogy a „betegség esetén” fordulat nem azt jelenti, hogy a betegség vagy egyéb típusú egészségromlás (pl. baleset) szükségszerűen maga a biztosítási esemény is lenne. Például utólagos megtéritést biztosító egészségbiztosítások esetén a biztosítási esemény az orvosi ellátás igénybevétele, nem pedig a betegség jelentkezése
(Langheid-Wandt, 2009-2010). Végül megemlítjük, hogy a Ptk. fent idézett meghatározásának második mondata is kiterjesztően értelmezendő, mert egészségügyi szolgáltatások egészséges személy általi igénybevétele esetén a biztosító nemcsak a felmerülő költségeket térítheti meg, hanem az egészségügyi ellátáshoz való hozzáférést is biztosíthatja szolgáltatásfinanszírozó - a biztosító a biztosítási esemény bekövetkezésekor nem pénzben, hanem természetben nyúitja a szolgáltatását úgy, hogy a szükséges orvosi ellátásnak az igénybevételét teszi lehetővé a biztosított számára, és az adott egészségügyi szolgáltató által nyújtott egészségügyi szolgáltatás költségét a szolgáltatónak megtéríti - egészségbiztosításként.

\section{Az egészségbiztosítások jelene}

Az egészségbiztosítási szerződési piac igencsak csekély méretű volt a Ptk. 2014-es hatályba lépése előtt: pl. 2011-ben csak négy hazai biztosító kínált önállóan köthető egészségbiztosítási terméket (Vállyon 2011). Azóta pedig azt lehet megfigyelni, hogy időről időre felmerülnek olyan vélemények, hogy a piac fejlődésében már rövid távon is ugrásszerü változások várhatóak (Portfolio 2016), ezek azonban a mai napig nem jelentkeztek, legfeljebb csak igen visszafogott fejlődést lehet érzékelni.

Az egészségbiztosítások elterjedésének jelenleg számos gátja van. Ezek közül elsőként a hálapénzt említenénk (Világgazdaság 2014). Ugyanis annak ellenére, hogy mind az orvosok (Szinapszis 2017), mind a lakosság (Szinapszis 2013) jobban szeretne egy hálapénzmentes egészségügyi rendszert, a jelen körülmények között a többletszolgáltatások beszerzéséhez hatékonyabb, illetve kedvezőbb eszköznek minősül az egészségbiztosításoknál a hálapénz.

A másik lényeges probléma az, hogy nem állnak rendelkezésre az elvárt mennyiségben és minőségben az egészségügyi és az egészségügyi szolgáltatásokkal kapcsolatos adatok (Gulácsi 2016). Így a biztosítók az igazán nagy egészségügyi kockázatokra (pl. fekvőbeteg-ellátás keretében nyújtott egészségügyi szolgáltatásokat is fedező biztosítások) már csak emiatt sem tudnak egészségbiztosítási termékeket fejleszteni.

Ehhez kapcsolódik az a bizonytalanság, hogy a magán- és közellátás viszonya az egészségügy területén sem a finanszírozás, sem a szolgáltatásnyújtás vonatkozásában nem tisztázott (Kovács és mtsai. 2015). Sem az a kérdés nincs megnyugtatóan rendezve, hogy az állami kórházakban mennyiben lehet magánszolgáltatásokat nyújtani, sem pedig az, hogy a piaci szereplők mikor, milyen feltételekkel vehetnek részt a társadalombiztosítás által fedezett egészségügyben: legalábbis a szabályozás és a gyakorlat közötti diszkrepancia ezt mutatja. Ami a fenti gátló tényezők ellenére kisebb lökést adhatott az egészségbiztosítások elterjedésének, az egy 2012-es jogszabályváltozás volt, amely a munkáltató által kötött egészségbiztosítások dijját az adó- és járulékmentes juttatások körébe sorolta. Az ezzel kapcsolatos túlzó szakmai várakozások nem teljesültek (MABISZ 2016). Az utóbbi években is csak csekély növekedés figyelhető meg az egészségbiztosítási piacon: például 2016-ban a díjbevétel közel 13 százalékkal, a szerződések száma pedig 5 százalékkal növekedett (MABISZ 2016). Bár ezek még mindig nem túl magas értékek az 
egyéb biztosítástípusokhoz képest (MNB 2017), ugyanakkor egy újabb kutatás azt jelzi, hogy a munkáltatók érdeklődése nő a cafeteria keretében nyújtható biztosítások iránt: 2015-ben csak a válaszadók 13, 2017-ben viszont már 27 százaléka kínált biztosítást a juttatási rendszerében (MABISZ Sajtóközlemény 2017).

A 2011-es mélyponthoz képest egyértelműen pozitív változásként említhető az, hogy egyre több biztosító nyúit egészségbiztosítási terméket. Összegbiztosítást szinte valamennyi hazai biztosító kínál (Portfolio 2017), és mintegy tíz biztosító kínál szolgáltatásfinanszírozó egészségbiztosítást, ezek közül többen csoportos biztosításokat vagy azt is (Balázs 2017). Az utólagos költségtérítést szolgáltató egészségbiztosítások (a biztosító arra vállal kötelezettséget, hogy a biztosított által kiválasztott intézményben igénybe vett egészségügyi szolgáltatások költségét utólag, számla ellenében megtéríti) viszont a magyar piacra nem jellemzőek.

Azt is meg kell azonban jegyeznünk, hogy ezek a biztosítási termékek - elsősorban a szolgáltatásfinanszírozó biztosításokra gondolunk - meglehetősen korlátozott körben nyújtanak szolgáltatásokat. Ez azt jelenti, hogy jellemzően legfeljebb az alapellátásokat, járóbeteg-ellátásokat, diagnosztikai szolgáltatásokat (többek között második orvosi vélemény), egynapos sebészeti ellátásokat és a kórházi hotelszolgáltatásokat tartalmazzák. Így - ahogyan már fent is említettük - jellemzően nem nyújtanak fedezetet a fekvőbeteg-ellátás keretében nyújtott egészségügyi szolgáltatásokra. Ennek oka a korábban említett információhiány mellett az, hogy hiányzik az ilyen termékekre a fizetőképes kereslet. Hiszen a mostani egészségbiztosítások átlagos díja havi ötezer forint körül mozog (Portfolio 2017), és ezt az összeget is csak a lakosság 28 százaléka lenne hajlandó megfizetni (UNION 2017). Bár korábbi kutatások azt mutatják, hogy a tényleges egészségügyi szolgáltatások esetében (kórházi ellátás, műtét stb.) már nagyobb a fizetési hajlandóság (Baji és Gulácsi 2012)

Végül a másik hiányossága az elérhető biztosítási termékeknek, hogy a többségük csak 65 éves korig nyújt biztosítási fedezetet, és inkább kivételnek minősülnek azok a biztosítások, amelyek akár 70 vagy 80 éves korig is védelmet adnak. Tehát éppen azon a személyek - a 65 év feletti lakosság - részére nincs elérhető magán-egészségbiztosítás, akiknek a legnagyobb szükségük lenne rá.

\section{A Ptk. hatálybalépésének hatásai}

Mivel az egészségbiztosításokhoz füződő legfontosabb kérdések és problémák politikai, illetve közjogi jellegűek, ezért a Ptk. által bevezetett magánjogi szabályozásnak értelemszerüen nem lehetett és önmagában nem is lehet jelentős hatása az egészségbiztosítások piacára. Ráadásul a jogalkotó a Ptk. szabályozásának kidolgozása során meglehetősen visszafogott volt, és nem vezetett be olyan megoldásokat, amelyek lényegesen változtattak volna a korábbi gyakorlaton. Ilyen gyökeres változás lett volna például az alábbi megoldások bevezetése: kötelező befogadás (open enrolment): a biztosító valamennyi ügyféllel köteles biztosítást kötni, függetlenül attól, hogy milyen egészségbiztosítási kockázatokkal rendelkezik, lásd pl. Belgiumot (Gerken-Merkur);

közös díjszabás (community rating): a biztosítók valamennyi ügyfelüknek azonos díj ellenében kötelesek biztosítást nyújtani, lásd pl. Írországot (HIA);

vagy az élethosszig tartó fedezet (lifetime cover): a biztosítások csak határozatlan időre szólhatnak, és a biztosítók rendes felmondással nem szüntethetik meg azokat, lásd pl. Ausztráliát (PHIO).

\section{I jogalkotó jelentős reformokra nem vállalkozott.}

A jogalkotó azonban ilyen jelentős reformokra nem vállalkozott. Ugyanis a Ptk. az egészségbiztosítási szerződések vonatkozásában a definíción és az utaló szabályokon kívül csak két részletkérdést tárgyal. Ezek közül az egyik a várakozási idő, amelynek hat hónapot meghaladó részét két kivétellel (ápolási biztosítások és meglévő, mindkét fél által ismert betegségekhez kapcsolódó kockázatok) semmisnek minősíti. Ez az új szabályozás azért nem hozott lényegi változásokat, mert a biztosítók korábban sem alkalmaztak hat hónapnál hosszabb várakozási időt. Megemlítjük azonban, hogy ez a rendelkezés akadályát képezheti olyan új termékek megjelenésének, amelyeknél hat hónapnál hosszabb várakozási idő alkalmazása indokolt (pl. terhesség, mesterséges megtermékenyítés).

A másik új részletszabály a szerződés felmondására vonatkozik. Ennek keretében a Ptk. - fogyasztói biztosítás esetén kógens módon - kizárja a biztosító rendes felmondási jogát. E rendelkezésnek akkor lenne igazán jelentősége, ha a biztosításokat csak határozatlan időre lehetne kötni (ez lenne az élethosszig tartó fedezet), azonban ez utóbbi szabályt a Ptk. nem tartalmazza, így a hazai egészségbiztosítások jellemzően továbbra is határozott ideig, legfeljebb a biztosított 65 éves koráig tartanak. Annyi hatása azonban van az új kódexnek, hogy visszaszorulóban vannak azok a biztosítások, amelyeknél a szerződés egyéves határozott időre szól, és minden esetben egy újabb évvel meghosszabbodik a biztosítási évfordulón, ha ez ellen a biztosítási év letelte előtt legalább 30 nappal egyik fél sem tiltakozik. Hiszen ezzel a megoldással a biztosítónak ugyanúgy minden biztosítási évfordulón lehetősége van arra, hogy indoklás nélkül megszüntesse a szerződést, mintha rendes felmondási joga lenne. Ez az eredmény azonban a jogszabály megkerülésének minősíthető a kvázi rendes felmondási jog miatt. Álláspontunk szerint ez az oka annak, hogy egyre kevesebb az ilyen termék a hazai biztosítási piacon.

A Ptk. a felmondás kapcsán még a biztosítási kockázat növekedésének kérdésével foglalkozik, és kifejezetten arról rendelkezik, hogy a biztosított életkora előrehaladásából származó természetes egészségromlás lehetősége nem minősül annak. Ez szintén nem jelent érdemi változást, hiszen az egészségbiztosítás elveszítené az értelmét, ha a biztosító a természetes egészségromlásra hivatkozva módosithatná vagy megszüntethetné a szerződést. Annál jelentősebb hatása lett 
volna annak, ha a Ptk. a teljes kockázatközösségre vonatkozó kockázatok változásakor (pl. a várható élettartam növekedése, a technika fejlődése stb.) alkalmazható, a biztosítót megillető szerződésalakító jogot is szabályozta volna. A 2009-es Ptk. ugyanis úgy rendelkezett, hogy ha a veszélyközösséget érintően következtek volna be a díj számítási alapjaira kiható változások, akkor a biztosító jogosult lett volna a szerződés módosítására, de e módosítások szükségességét és indokoltságát független szakértőnek kellett volna felülvizsgálnia és igazolnia. Ezt a megoldást egyébként Németországban alkalmazzák (Voit 2017). A Ptk.-ba azonban nem kerültek be ezek a szabályok, így értelemszerűen a gyakorlati hatásuk is elmaradt.

Végül csak röviden utalunk a Ptk.-nak még egy hatására, ez pedig az egészségbiztosítás kifejezés használatának terjedése. Ezt mutatja az, hogy a hazai biztosítók ma már lényegében csak ezen elnevezés alatt kínálják termékeiket. Ugyanakkor a Ptk. után elfogadott, a biztosítási tevékenységről szóló 2014. évi LXXXVIII. törvény (új Bit.) mind a betegség-, mind az egészségbiztosítás kifejezést használja, valamint az MNB által közölt piaci adatokban (MNB 2017) is megjelenik mind a betegség-, mind az egészségbiztosítás kifejezés. A megkülönböztetést egyértelműen nem magyarázzák, valószínűleg a betegségbiztosítások alatt a kárbiztosításokat, az egészségbiztosítások alatt pedig az összegbiztosításokat értik. Álláspontunk szerint azonban szerencsésebb lenne az egységes szóhasználat.

\section{Konklúzió - az egészségbiztosítások perspektívái}

Ahogyan a fentiekből következik, a hazai egészségbiztosítási piac továbbra is gyerekcipőben jár, és ezen a Ptk. hatálybalépése és az általa bevezetett szabályozás értelemszerüen nem tudott változtatni. Ahhoz, hogy e területen számottevő előrelépés legyen, a közjogi kereteken kellene változtatni, egyelöre azonban nem látszik, hogy meglenne ehhez a kellő politikai akarat. Pedig bőven lenne teendő. Így többek között ténylegesen fel kellene lépni a hálapénz ellen, növelni kellene az egészségügy átláthatóságát, hogy kellő mennyiségü valós adat álljon rendelkezésre az egészségbiztosítási termékek tervezéséhez, valamint ki kellene jelölni a magánszféra szerepét az egészségügyi rendszerben, azaz tisztázni kellene az állami és magánegészségügy egymáshoz való viszonyát.

Ezekre a lépésekre azért is lenne nagy szükség, mert hiába nő az utóbbi években jelentősen a magánszolgáltatók által ellátott betegek száma (Gulácsi 2016), a magánbiztosítások körében a növekedés érezhetően kisebb mértékű. Ráadásul az egészségbiztosítások piacán nem az lenne az igazi áttörés, ha a jelenlegi termékek jobban elterjednének, hanem az, ha megjelennének a jelentősebb egészségügyi kockázatokat, azaz a fekvőbeteg-ellátást is fedező egészségbiztosítások. Ugyanakkor még a fenti előfeltételek megvalósulása esetén sem látszik az, hogy lenne fizetőképes kereslet az ilyen termékek iránt. Az ilyen biztosításokat azzal lehetne elérhetővé tenni, ha legalább részben megszűnne a jelenlegi kétszeres fizetési kötelezettség. Ez azt jelentené, hogy azokban az esetekben, amikor a biztosított olyan szolgáltatást vesz igénybe a magánbiztosításán keresztül, amely neki egyébként a társadalombiztosítás keretében is járna, akkor a magánbiztosító legalább részben meg- kapná azt a finanszírozást, amelyet az egészségügyi szolgáltató a társadalombiztosítás keretében kapna, hiszen a magánbiztosítás ilyenkor tehermentesíti a társadalombiztosítást. Ezzel a megoldással valamennyi fél jól járna, és jelentősen csökkenthető lenne a magánbiztosítások díja.

\section{IRODALOMJEGYZÉK}

Baji P. és Gulácsi L. (2012): A magyar lakosság fizetési hajlandósága az egészségügyi ellátásokért - egy reprezentatív kérdöives felmérés eredményei. Biztositási Szemle

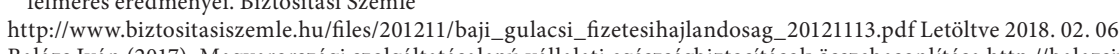

Balázs Iván (2017): Magyarországi szolgáltatásalapú vállalatit egészségbiztositások összehasonlitása http://balazsivan.hu/szolgalGerken-Merkur (2010): Belgium: Health System Review. Health Systems in Transition http://www.euro.who.int/_data/assets/ pdf_file/0014/120425/E94245.PDF Letöltve 2018.01.26.

Gulácsi L. (2016): A magánfinanszírozás helye a magyar egészségügyben; forráshiányban az egészségügy - Mit tehetnek a biztosítók. Biztositás és Kockázat 2016/2. pp. 88-97.

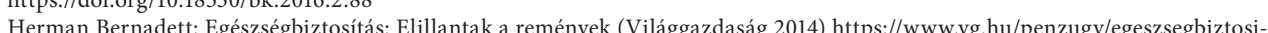
tas-elillantak-a-remenyek-426217/ Letöltve 2018.01.26

HIA: Health Insurance Authority http://www.hia.ie/ Letöltve 2018.01.26.

Kovács E. - Kiss N. - Kovács E. - Tỏkey B.: (2015): A magán-egészségbiztositás helyzete, szerepe és lehetőségei - Európai kitekintés és magyarországi helyzetkép, BOKCS-MABISZ Kutatás, Budapest

Langheid-Wandt (szerk., 2009-2010): Münchener Kommentar zum Versicherungsvertragsgesetz, Beck, München
Magyar Biztositók Évkönyve 2016 (MABISZ 2016) http://www.mabisz.hu/images/stories/docs/publikaciok/evkonyv-2016-magyar.pdf Letöltve 2018.01.26.
Magyar Biztositok Evkönyve 2017 (MABISZ2017) http://www.mabisz.hu/images/stories/docs/publikaciok/evkonyv-2017-magyar.pdf

Letöltve 2018.01.26.

Magyar Biztositók Szövetsége - Nő a biztositások népszerüsége a munkáltatók körében Sajtóközlemény - 2017.11.15. (MABISZ Sajtóközlemény 2017) http://www.mabisz.hu/images/stories/docs/sajto/mabiszsajtotajekoztato20171115.pdf Letölttve 2018. 02.06.

PHIO: Private Health Insurance Ombudsman http://www.phio.org.au/ Letöltve 2018.01.26.

a Polgári Törvénykönyvről szóló 2013. évi V. törvény miniszteri indokolása

Portfolio Private Health Forum 2017 (Portfolio 2017) https://www.portfolio.hu/finanszirozas/biztositok-penztarak/biztositok-az-egeszsegugyben-nagy-attores-jon-a-valasztasok-utan.264455.html Letöltve 2018.01.26

列 2018.01.26.

Robbanásszerủ lesz az átalakulás az egészségbiztositási piacon (Portfolio 2016) https://www.portfolio.hu/finanszirozas/biztositok-penztarak/robbanasszeru-lesz-az-atalakulas-az-egeszsegbiztositasi-piacon.241193.html Letöltve 2018.01.26.

szinapszis Kft. 2013-as kutatása a hálapénzről (Szinapszis 2013) http://www.szinapszis.hu/hu/hirek/azonnali-beavatkozast-surget-a-halapenz-problemajanak-megoldasa Letöltve 2018.0126.

Szinapszis Kft. 2017-es kutatás a hálapénzzôll (Szzinapszis 2017) http://reszasz.hu/index.php/104-szinapszis-sajat-tanulmany-ha-

UNION Biztositó 2017-es piaci felmérése (UNION 2017) https://biztositomagazin.hu/2017/12/20/a-hosszu-varolistak-miatt-lesz-nepszerubb-a-magan-egeszsegbiztositas/ Letöltve 2018.01.26

Vallyon, A. (2011). A kiegeszzito biztositások szerepe a2 eészségugugyben az Európai Unióban és Magyarországon, Doktori értekezés https:///szie.hu//file/tti//archivum/Vallyon_Andrea_ertekezes.pdf Letöltve 2018.01.26

Voit W: Der Treuhänder be Prämienat und ihre rechtliche Überprüfung. Versicherungsrecht 2017/12., pp. 727-733. 